\title{
The Relevance Of United States GAAP Information Provided By Foreign Firms In SEC's Form 6-K
}

\author{
Jeannie Johnson Harrington (E-mail: jharrington@mtsu.edu), Middle Tennessee State University
}

\begin{abstract}
This study examines SEC Form 6-K to determine whether foreign firms report U.S. GAAP adjusted financial information before filing their annual SEC Form 20-F. This study then performs tests to determine whether the financial information in Form 6-K provides relevant information to investors. The results are inconclusive concerning the relevance of this information to investors. Other tests were performed to determine whether there was a difference between the relevance of the information provided in Form 20-F for those companies not disclosing any U.S. GAAP information prior to the Form 20-F filing date and those companies providing prior U.S. GAAP data in Form 6-K. These tests did not reveal a significant difference, an unexpected finding. Overall, results indicate that SEC Form 6-K rather than annual Form 20-F contains more timely, financial information for most foreign companies.
\end{abstract}

\section{Introduction}

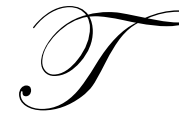

he Securities and Exchange Commission (SEC) requires all foreign firms listing on United States (U.S.) stock exchanges to provide financial information under U.S. generally accepted accounting principles (GAAP) annually in Form 20-F. Foreign firms can either prepare their financial statements using U.S. GAAP or they can prepare financial statements using their home country GAAP and reconcile net income and stockholders' equity figures to U.S. GAAP equivalents. The majority of foreign firms choose to reconcile. This U.S. GAAP requirement has been a source of controversy between the SEC and the various U.S. stock exchanges for many years ${ }^{1}$, with officials at the stock exchanges questioning the relevance of this onerous task.

Previous research concerning the relevance of the U.S. GAAP requirement has focused mainly on U.S. GAAP reconciliations. Several studies have examined the relevance of U.S. GAAP reconciliations; reported results have been mixed. Most of the previous studies have used the Form 20-F filing deadline as part of their event window for testing relevance. Because Form 20-F is not due until six months after fiscal year end and most firms file Form 20-F near the end of the six-month deadline, timeliness is often given as one reason for lack of relevance of U.S. GAAP information. McQueen [1993], Amir, Harris, and Venuti [1993], and Harrington, [1998] have examined event periods earlier than the Form 20-F filing. These studies examined earlier event periods because some firms provide U.S. GAAP reconciliations in their annual reports or their media-released annual earnings announcements. Companies generally release both of these documents earlier than they file Form 20-F. However, the Amir et. al. and Harrington studies found that a majority of firms release their annual U.S. GAAP-reconciled information first in Form 20-F. ${ }^{2}$

Although Form 20-F is the only document that must be filed by all foreign filers; another document, SEC Form $6-\mathrm{K}$, is often filed by foreign firms to report "the occurrence of any material events or corporate changes" not previously reported to investors. Form 6-K may be filed any time during the year. Analysts familiar with SEC filings have stated that U.S. GAAP financial information is sometimes provided earlier than either the annual report release or yearly Form 20-F filing in Form 6-K. ${ }^{3}$ 
Regarding interim reporting, the SEC requires only a semi-annual report of non-adjusted earnings filed on Form 6-K if and when firms are required to report interim earnings in their home country [Frost and Pownall, 1994a]. Thus, the SEC only requires U.S. GAAP information to be provided on an annual basis. However, some firms may voluntarily provide U.S. GAAP information throughout the year on Form 6-K.

Given mixed results from the previous 20-F studies, the main goal of the current examination is to determine whether any U.S. GAAP information is provided to the SEC prior to the annual Form 20-F filing and if provided, whether this data is relevant to investors, as evidenced by a stock market reaction. Form 6-K documents are examined to determine if any U.S. GAAP information is provided prior to the Form 20-F filing. In addition, information provided in the annual Form 20-F filing by companies that disclose U.S. GAAP information in Form 6-K prior to the Form 20-F filing and by companies that do not previously disclose any U.S. GAAP information are examined to determine comparative relevance of the reporting alternative.

U.S. GAAP information provided in the Form 6-Ks is expected to be relevant, helping to explain why some studies find insignificance of information provided in Form 20-F filings. The opposite finding is anticipated regarding relevancy of information provided by those firms not disclosing prior U.S. GAAP information, i.e., the information provided in Form 20-F should be relevant for those firms first disclosing U.S. GAAP information at the Form 20-F filing date.

Examined first is U.S. GAAP information provided in SEC Form 6-K, which is considered "current" by practitioners. Researching the relevance of SEC Form 6-K allows the investigation of practitioners' claims of relevance of information provided in this particular document. With the advent of the Electronic Data Gathering Analysis and Retrieval (EDGAR) Internet Database in 1994, a greater variety of investors and others have immediate access to any electronically filed SEC documents. This study provides insight for these interested parties as to whether Form 6-K can be examined to secure the most current and relevant financial information available.

The next section of the paper reviews the prior research on the relevance of SEC Documents and U.S. GAAP information. The third section explains the research design used to determine whether the U.S. GAAP information is significant. The fourth section presents the empirical results and analyses, and the last section summarizes the findings and presents the conclusions.

\section{Prior Research}

Existing research can be divided into two categories: 1) studies pertaining to the relevance of SEC documents and 2) studies pertaining to the relevance of U.S. GAAP information. These studies are discussed in the following sections.

\subsection{SEC Documents}

Previous studies on the relevance of SEC documents filed by U.S. firms provide mixed findings. The relevance of SEC documents was first examined in Foster and Vickrey [1978] with a sample of 96 Form 10-Ks filed in 1973. Using a five-day event window beginning the day the $10-\mathrm{K}$ was officially released, they found a stock market reaction to the 10-K release when an annual report was filed at least ten days before the 10-K filing. However, a subsequent study by Foster, Jenkins, and Vickrey [1983] examined 159 Form 10-Ks for 1975 and 1977 and found no significant stock market reaction to the 10-K filings. Stice [1991] provided additional support of nonsignificance of SEC documents when he used a three-day event window to examine 342 Form 10-Ks and 10-Qs filed at least four days prior to earnings announcements. He found no significance in the stock market reaction to the SEC documents. Mixed results of these studies, along with mixed results from several other studies which indirectly tested the informativeness of SEC documents prompted Easton and Zmijewski [1993] to conduct a massive study of the informativeness of annual 10-K, annual report, and interim 10-Q filings. Easton and Zmijewski examined 76,866 10-K filings, 48,107 annual report filings, and 193,283 10-Q filings. They found few significant stock market reactions to the release of the 10-K or the10- 
Q filings. They concluded that "using the earlier of the SEC annual report or 10-K dates as the date of the first public disclosure of the information in the annual report may introduce considerable error."

For SEC documents filed by foreign companies, Meek [1983] conducted the seminal study. He examined the stock market reaction to Form 20-K (the current 20-F) and found no significant stock market reaction in the week the 20$\mathrm{K}$ was filed. He attributed the insignificant market reaction to the untimeliness (six months after fiscal year end) of the Form 20-K filing. Relevance of Form 20-F has since been indirectly examined by Amir, Harris, and Venuti [1993], McQueen [1993], Bandyopadhyay, Hanna, and Richardson [1994], Rees [1995] and Rees and Elgers [1997]. In the various studies, examinations of short event windows of five to ten days surrounding the Form 20-F filing and one year association periods were conducted. Rees found the most conclusive results of relevance of the Form 20-F filing. McQueen's results were mixed, while Amir et. al., Bandyopadhyay et. al., and Rees and Elgers found no significance of the Form 20-F filing. McQueen's small reaction to the Form 20-F filing and Rees and Elgers' non-association of reconciling items and securities returns allowed them to conclude that the information provided in Form 20-F appears to be available before the Form 20-F filing date. In addition to the above studies, Frost and Pownall [1994a] examined the contents of Form 6-Ks filed by United Kingdom (U.K.) companies but they did not specifically address the relevance of the information provided.

\subsection{U.S. GAAP Data}

Most of the earlier studies have examined the relevance of the information provided by U.S. GAAP reconciliations. Some of the prominent studies on this issue include Pope and Rees [1992], Barth and Clinch [1996], Chan and Seow [1996], and Fulkerson and Meek [1998], along with the aforementioned Amir et. al, McQueen, Bandyopadhyah et. al., Rees, and Rees and Elgers studies. These studies examined whether the U.S. GAAP reconciliations provided in Form 20-F contain relevant information. Results have been mixed. Amir et. al., McQueen, Rees, Barth and Clinch, Chan and Seow and Rees and Elgers find significance of at least some of the U.S. GAAP adjustments, and conversely, Bandyopadhyay et. al. did not find significance in any U.S. GAAP adjustments for Canadian firms exclusively. Pope and Rees found that U.S. GAAP net income was significant but determined that this figure did not provide significant information over U.K. GAAP net income. Fulkerson and Meek found that U.S. GAAP reconciliations appear to be relevant for companies from countries with very dissimilar GAAP from the U.S. In summarizing the above literature on value relevance of GAAP restatements, Saudagaran and Meek [1997] concluded that the empirical evidence to date has not been overwhelmingly in favor of restatements with existing evidence supporting both sides.

The proper event date for determining relevance of U.S. GAAP information is the first time this information is available to the public. One of the main reasons given for the lack of conclusive results in the above studies is timeliness of the disclosures examined. Previous studies indicate that the filing of the SEC's Form 6-K document will not provide significant information if Form 20-F is filed before Form 6-K. However, since Form 6-K can be filed at any time throughout the year, the timeliness of any U.S. GAAP information provided in Form 6-K anticipates significance when filed before the annual Form 20-F.

\section{Research Design}

The first goal of this research study is to determine whether any U.S. GAAP information is provided to the SEC in Form 6-K prior to the Form 20-F filing. Firms have the option of providing U.S. GAAP-prepared financial statements or providing a reconciliation of their foreign GAAP to U.S. GAAP. Both of these types of information are considered "U.S. GAAP" information and tested for relevancy. The first set of research questions addressed are as follows: 1) Is any U.S. GAAP information provided by foreign companies in Form 6-K before they file their annual Form 20-F? 2) If this information is available, does the U.S. GAAP information provided by foreign companies in Form 6-K contain relevant information? In addition, the possibility of differences in the relevance of the information provided in the annual Form 20-F between those companies providing U.S. GAAP information prior to the Form 20-F filing and those companies not providing any prior U.S. GAAP information is investigated as the second goal of the research study. In 
order to perform desired tests, the relevance of the non-U.S. GAAP financial information of those companies not providing prior U.S. GAAP information is examined as well. The research questions to address these tests are as follows: 3) Is the non-U.S. GAAP financial information provided in Form 6-K prior to the Form 20-F filing relevant to investors? and 4) Is there a difference between those companies reporting U.S. GAAP information prior to the Form 20-F filing and those companies not reporting prior U.S. GAAP information? Research questions expressed as null hypotheses are as follows:

$\mathrm{Ho}_{1}$ : There is no stock market reaction to the release of U.S. GAAP information in Form 6-K at the event date.

$\mathrm{Ho}_{2}$ : There is no stock market reaction to the release of non-U.S. GAAP financial information in Form 6-K at the event date.

Ho $:$ There is no difference between the stock market reaction to the release of Form 20-F of those companies reporting U.S. GAAP information prior to the Form 20-F filing date and those companies not reporting prior U.S. GAAP information.

For purposes of this study, "relevance" of information is defined as an abnormal stock market reaction to the financial information at the event date, which is the three-day period centered on the SEC filing date of the respective Form 6-K or Form 20-F. The event-study model used to determine whether the stock market reactions are abnormal is based on the methodology of Frost and Pownall [1994b]. In addition, a t-test of the two population means will be used to evaluate $\mathrm{Ho}_{3}$.

\subsection{Sample}

All foreign firms from six selected countries listed on the New York Stock Exchange (NYSE), the American Stock Exchange (ASE) or the National Association of Securities Dealers Automated Quotation System (NASDAQ) in the fiscal years 1993-1994 were included in the sample population. With the exclusion of the U.S., the countries are selected according to Zarzeski's [1996] sample which contains countries from a variety of cultures. Included in the sample are companies from the following countries: 1) France, 2) Germany, 3) Hong Kong, 4) Japan, 5) Norway, and 6) the U.K. As of June 30, 1995, 119 companies were included in the sample population. The sample population was adjusted for the following exclusions:

- $\quad$ Companies not containing stock return information through the Center for Research on Stock Prices (CRSP) tapes. This criterion excluded 21 firms.

- $\quad$ Companies not filing Form 6-Ks with the SEC during the test period. This requirement eliminated 13 firms.

- $\quad$ Companies exempt ${ }^{4}$ from filing U.S. GAAP information. This requirement removed 5 firms.

Applying the sample selection criteria, data for 80 usable firms was retained. The majority of the firms, 48 $(60 \%)$, are domiciled in the U.K., with the second largest number of firms, $15(19 \%)$, from Japan. The remainder of the sample contains 7 firms from France (9\%), 1 from Germany (2\%), 5 from Hong Kong (6\%), and 4 from Norway (5\%).

This study examines only those 6-Ks containing financial statement information. Many other 6-Ks are filed by these companies with the SEC throughout the sample years that contain other types of information including financial forecasts, merger and acquisition announcements, news releases, new product information, management changes, capital structure changes, dividend announcements, etc. From the 80 sample firms, 493 financial 6-Ks were filed in the 19931994 fiscal year periods. This represents a per company average (median) of 6.2 (5.5) 6-Ks containing financial information filed in the two-year period. As mentioned earlier, companies are not required to provide any U.S. GAAP information in the 6-Ks. Disclosing this information is strictly voluntary. Of the 493 6-Ks, 276 (56\%) contained U.S. GAAP financial information and 217 (44\%) contained non-U.S. GAAP information. In addition, the U.S. GAAP 6-Ks are classified according to the financial information provided as follows: 1) U.S. GAAP-prepared financial information 132 (48\%), or 2) U.S. GAAP- reconciled financial information - 144 (52\%). 
Table 1 documents the sample 6-K documents by domicile and stock exchange. By domicile of the companies, once again, the majority of the 6-Ks (58\%) were provided by U.K. firms for an average (median) of 6.0 (5.0) 6-Ks each. Japanese companies provided the second most documents (24\%) for an average (median) of 8.0 (8.0) 6-Ks per firm. French firms provided 7\% of the documents for an average (median) of 5.1 (6.0) 6-Ks per firm, while Norwegian firms provided $6 \%$ of the documents for an average (median) of 7.0 (7.0) 6-Ks per firm. Finally, the Hong Kong and German companies provided $4 \%$ and $1 \%$ of the documents, respectively, with the Hong Kong firms providing 3.8 (3.0) 6-Ks and the German firm providing 3.0 (3.0) 6-Ks over the two year sample period.

Table 1: Sample 6-K Documents

\begin{tabular}{lcccccrr}
\hline By Country & France & Germany & $\begin{array}{r}\text { Hong } \\
\text { Kong }\end{array}$ & Japan & Norway & $\begin{array}{c}\text { United } \\
\text { Kingdom }\end{array}$ & Total \\
\hline Sample Firms & 7 & 1 & 5 & 15 & 4 & 48 & 80 \\
Form 6-K Documents & 36 & 3 & 19 & 120 & 28 & 287 & 493 \\
\% of Total 6-K Sample & $7 \%$ & $1 \%$ & $4 \%$ & $24 \%$ & $6 \%$ & $58 \%$ & $100 \%$ \\
Average 6-Ks & 5.1 & 3.0 & 3.8 & 8.0 & 7.0 & 6.0 & 6.2 \\
Median 6-Ks & 6.0 & 3.0 & 3.0 & 8.0 & 7.0 & 5.0 & 5.5 \\
U.S. GAAP Information & 4 & 2 & 5 & 83 & 27 & 155 & 276 \\
Non-U.S. GAAP Information & $\underline{32}$ & $\underline{1}$ & $\underline{14}$ & $\underline{37}$ & $\underline{1}$ & $\underline{132}$ & $\underline{217}$ \\
$\quad$ Total Form 6-Ks & $\underline{\underline{36}}$ & $\underline{\underline{3}}$ & $\underline{\underline{19}}$ & $\underline{\underline{120}}$ & $\underline{\underline{28}}$ & $\underline{\underline{287}}$ & $\underline{\underline{493}}$ \\
U.S. GAAP Information: & 4 & 0 & 3 & 83 & 24 & $\underline{18}$ & 132 \\
$\quad$ U.S. GAAP-Prepared & $\underline{0}$ & $\underline{2}$ & $\underline{2}$ & $\underline{0}$ & $\underline{3}$ & $\underline{137}$ & $\underline{144}$ \\
$\quad$ U.S. GAAP-Reconciled & $\underline{4}$ & $\underline{2}$ & $\underline{\underline{5}}$ & $\underline{83}$ & $\underline{27}$ & $\underline{155}$ & $\underline{276}$ \\
$\quad$ Total U.S. GAAP 6-Ks & & & & & & &
\end{tabular}

\begin{tabular}{|c|c|c|c|c|}
\hline By Stock Exchange & $\begin{array}{c}\text { NYSE/ } \\
\text { ASE }\end{array}$ & $\%$ & NASDAQ & $\%$ \\
\hline Sample Firms & 52 & $65 \%$ & 28 & $35 \%$ \\
\hline Form 6-K Documents & 349 & $64 \%$ & 144 & $36 \%$ \\
\hline Average 6-Ks & 6.71 & & 5.14 & \\
\hline Median 6-Ks & 6.00 & & 5.00 & \\
\hline U.S. GAAP Information & 208 & $60 \%$ & 68 & $47 \%$ \\
\hline Non-U.S. GAAP Information & $\underline{141}$ & $40 \%$ & $\underline{76}$ & $53 \%$ \\
\hline Total Form 6-Ks & $\underline{\underline{349}}$ & & $\underline{\underline{144}}$ & \\
\hline \multicolumn{5}{|l|}{ U.S. GAAP Information: } \\
\hline U.S. GAAP-Prepared & 88 & $42 \%$ & 44 & $65 \%$ \\
\hline U.S. GAAP-Reconciled & $\underline{120}$ & $58 \%$ & $\underline{24}$ & $35 \%$ \\
\hline Total U.S. GAAP 6-Ks & $\underline{\underline{\underline{208}}}$ & & $\underline{\underline{\underline{68}}}$ & \\
\hline By Report Period & Interim & $\%$ & Annual & $\%$ \\
\hline Form 6-K Documents & 314 & $64 \%$ & 179 & $36 \%$ \\
\hline U.S. GAAP Information & 171 & $54 \%$ & 105 & $59 \%$ \\
\hline Non-U.S. GAAP Information & $\underline{143}$ & $46 \%$ & $\underline{74}$ & $41 \%$ \\
\hline Total Form 6-Ks & $\underline{\underline{314}}$ & & $\underline{\underline{179}}$ & \\
\hline
\end{tabular}




\begin{tabular}{|c|c|c|c|c|}
\hline U.S. GAAP-Prepared & 84 & $49 \%$ & 48 & $46 \%$ \\
\hline U.S. GAAP-Reconciled & $\underline{87}$ & $51 \%$ & $\underline{57}$ & $54 \%$ \\
\hline Total U.S. GAAP 6-Ks & 171 & & $\underline{105}$ & \\
\hline
\end{tabular}

Fulkerson and Meek [1998] suggest that U.S. GAAP reconciliations may be more relevant for firms with less financial analyst following. Previous studies have shown that those foreign firms traded on NASDAQ in lieu of the NYSE or the ASE have less analyst following and therefore, the information provided may be more relevant to investors. Accordingly, this study examines whether U.S. GAAP information provided in Form 6-K is more relevant for those firms listing on NASDAQ in lieu of the NYSE or the ASE. By stock exchange, $52(65 \%)$ of the final sample firms are listed on the NYSE or the ASE and $28(35 \%)$ firms are listed on NASDAQ. The NYSE/ASE firms filed 349 6-Ks (71\%) for an average (median) of $6.71(6.0)$ each, while the NASDAQ firms filed 144 6-Ks (29\%) for an average (median) of 5.14 (5.0) each. Of the financial 6-Ks filed by the NYSE/ASE firms, $208(60 \%)$ contained U.S. GAAP information and 141 (40\%) contained non-U.S. GAAP data. Of the U.S. GAAP data, 88 (42\%) 6-Ks contained U.S. GAAP-prepared data and $120(58 \%)$ contained U.S. GAAP-reconciled data. For the NASDAQ firms, $68(47 \%)$ contained U.S. GAAP information and $76(53 \%)$ contained non-U.S. GAAP data. Of the U.S. GAAP data, 44 (65\%) contained U.S. GAAP-prepared data and $24(35 \%)$ contained U.S. GAAP-reconciled data. Therefore, it appears that the NYSE/ASE firms are more likely to file financial Form 6-Ks and a little more likely to file 6-Ks containing U.S. GAAP data than the NASDAQ firms. Of the firms disclosing U.S. GAAP data, the NYSE/ASE firms appear more likely to reconcile to U.S. GAAP while the NASDAQ companies appear more likely to prepare U.S. GAAP financial statements. Additional tests will be conducted to determine whether the results are exchange related.

The 6-Ks containing financial data covered two distinct accounting periods: annual and interim. Annual information is not required to be submitted on Form 6-Ks but 63 of the 80 sample firms disclosed their annual results in a Form 6-K before the Form 20-F filing. Regarding interim information, the SEC only requires firms to file semi-annual financial results if a firm is required to do so in their home country. All of the countries examined required semi-annual reporting, with one of the countries also requiring quarterly reporting. Seventy-eight of the 80 firms filed Form 6-Ks containing semi-annual interim information, with 38 of the firms reporting interim results for either the first or the third quarters as well. Of the total documents, $314(64 \%)$ represent interim information and $179(36 \%)$ report fourth quarter or annual results. Of the interim information, $171(54 \%)$ contain U.S. GAAP information and 143 (46\%) contain nonU.S. GAAP data. Of the U.S. GAAP data, $84(49 \%)$ of the documents contained U.S. GAAP-prepared data and 87 (51\%) contained U.S. GAAP-reconciled data. Of the annual information, $105(59 \%)$ contained U.S. GAAP information and $74(41 \%)$ contained non-U.S. GAAP data. Of the U.S. GAAP data, $48(46 \%)$ of the documents contained U.S. GAAP-prepared data and 57 (54\%) contained U.S. GAAP-reconciled data. Thus, it appears slightly more likely that the 6-Ks containing annual information contain U.S. GAAP information than the 6-Ks containing interim data, and a little more likely that the U.S. GAAP information will be in reconciliation form. Additional tests will be conducted to determine whether the results are report period related.

\subsection{Stock Market Reaction Tests}

Stock market reactions are measured for the three-day event period centered on the date the appropriate document is filed with the SEC. The abnormal stock market reactions are based on squared, standardized stock price residuals derived from the following one-factor market model as follows:

$\mu_{\mathrm{it}}=\mathrm{R}_{\mathrm{it}}-\left(\alpha_{\mathrm{i}}+\beta_{\mathrm{i}} \mathrm{R}_{\mathrm{mt}}\right)$

where $\quad \mu_{\mathrm{it}}=$ stock return residual for firm $\mathrm{i}$ on day $\mathrm{t}$;

$\mathrm{R}_{\mathrm{it}}=$ CRSP return for firm $\mathrm{i}$ on day $\mathrm{t}$;

$\mathrm{R}_{\mathrm{mt}}=$ return on the CRSP NYSE/ASE equally-weighted index on day $\mathrm{t}$;

$\alpha_{i}$, and $\beta_{\mathrm{i}}$ are intercept and slope parameters for firm i estimated using the entire $759^{5}$ day sample period.

The stock return residuals for each of the three days in event period $\mathrm{k}$ are then squared and standardized by the firm-specific estimation period residual variance $\left(\sigma_{\mathrm{i}}^{2}\right)$. Then the squared standardized residuals are summed and divided 
by the three days in the event period to produce an abnormal return variable for each event, $\mathrm{AR}_{\mathrm{ikA}}$, with an expected value when the null hypothesis is true of 1 , as follows: 


$$
\begin{gathered}
\mathrm{t}=+1 \\
\mathrm{AR}_{\mathrm{ikA}}=\left[\begin{array}{c}
\left.\Sigma\left(\mu_{\mathrm{it}}{ }^{2 /} \sigma_{\mathrm{i}}{ }^{2}\right)\right] / 3 \\
\mathrm{t}=-1
\end{array}\right.
\end{gathered}
$$

As an additional safeguard, the abnormal event period is compared to a "normal" or nonevent three-day period arbitrarily designated as days -8 to $-10^{6}$ preceding the event period as in Frost and Pownall [1994b]. The nonevent period squared, standardized residual, $\mathrm{AR}_{\mathrm{ikNA}}$, is calculated as follows:

$$
\operatorname{Ar}_{\mathrm{ikNA}}=\left[\begin{array}{c}
\mathrm{t}=-10 \\
\left.\sum \sum_{\mathrm{t}=-8}\left(\mu_{\mathrm{it}}{ }^{2 /} \sigma_{\mathrm{i}}{ }^{2}\right)\right] / 3
\end{array}\right.
$$

Averages of these statistics across the $k$ events for firm $i$ during the two-year period to get $\mathrm{AR}_{\mathrm{iA}}$ and $\mathrm{AR}_{\mathrm{iNA}}$ are derived, then the difference between $\mathrm{AR}_{\mathrm{iA}}$ and $\mathrm{AR}_{\mathrm{iNA}}$, labeled $\mathrm{DIFF}_{\mathrm{i}}$, measures the average stock price response to each firm's financial information and has an expected value of zero under the null hypothesis of no relevance.

The relevance of each type of financial information is examined with a cross-sectional t-statistic. The t-statistic is computed by dividing the mean DIFF for all firms in each test partition by the standard deviation of the firm DIFFs divided by the square root of each test partition sample size. The $t$-statistic is then compared to the $t$ table to determine the outcome of the test of significance.

\subsection{Form 20-F Comparison Tests}

In order to test whether there is a difference in the relevance of the information provided by those companies providing U.S. GAAP information prior to the Form 20-F filing and those companies not providing prior data, the sample companies are classified as follows: 1) companies not providing prior U.S. GAAP information, or 2) companies providing prior U.S. GAAP information. Thirty-three firms did not disclose any U.S. GAAP data prior to the Form 20-F filing and 47 companies disclosed prior U.S. GAAP data. Seventy-four of the 80 sample firms are represented in the Form 20-F tests. CRSP data for the Form 20-F filing was not available for six of the sample firms and another six firms were inconsistent in their disclosure patterns, choosing to disclose U.S. GAAP data one year and non-U.S. GAAP data in another year.

Two sets of tests are performed on the Form 20-F information. First, t-tests are performed to determine whether there is a stock market reaction to the Form 20-F filing for each of the above classifications. The methodology for these tests is the same as the relevancy tests of the Form 6-Ks. Second, t-tests comparing the means of the DIFFs of the non-U.S. GAAP disclosing companies to the U.S. GAAP information disclosing companies are performed as follows:

$\mathrm{t}=\mathrm{x}_{1}-\mathrm{x}_{2} / \mathrm{S}_{\mathrm{x} 1-\mathrm{x} 2}$

where $\left.\quad \mathrm{S}_{\mathrm{x} 1-\times 2}=\left(\left(\left(\mathrm{n}_{1}-1\right) \mathrm{s}_{1}^{2}+\left(\mathrm{n}_{2}-1\right) \mathrm{s}_{2}^{2}\right) / \mathrm{n}_{1}+\mathrm{n}_{2}-2\right)\left(1 / \mathrm{n}_{1}+1 / \mathrm{n}_{2}\right)\right) 1 / 2$;

where $\mathrm{x}_{1}$ and $\mathrm{x}_{2}=$ mean DIFF of test partitions;

$\mathrm{n}_{1}$ and $\mathrm{n}_{2}=$ sample sizes of test partitions; and

$\mathrm{s}_{1}$ and $\mathrm{s}_{2}=$ test partition standard deviations;

Each t-statistic is compared to the t-table with $\mathrm{n}_{1}+\mathrm{n}_{2}-2$ degrees of freedom to determine significance.

\subsection{Adjustments To Sample Documents}

Table 2 details the adjustments which were made to the final 6-K and 20-F sample documents. These adjustments are discussed in the following paragraphs. 
Table 2: Adjustments To Sample Documents

\begin{tabular}{|c|c|c|c|}
\hline & $\begin{array}{c}\text { U.S. } \\
\text { GAAP }\end{array}$ & $\begin{array}{c}\text { Non-U.S. } \\
\text { GAAP }\end{array}$ & Totals \\
\hline \multicolumn{4}{|l|}{ Sample 6-K Documents } \\
\hline Form 6-K Financial Documents Filed & 276 & 217 & 493 \\
\hline \multicolumn{4}{|l|}{ Adjustments: } \\
\hline Earnings Announcement filed in event period & (41) & (38) & (79) \\
\hline \multicolumn{4}{|l|}{ Other significant news information released in } \\
\hline Duplicate financial information & (45) & (14) & (59) \\
\hline Form 6-K filed after Form 20-F filing & (19) & (3) & (22) \\
\hline No CRSP data for specific event period & (4) & (2) & (6) \\
\hline Outlier & (1) & & (1) \\
\hline \multicolumn{4}{|l|}{ Information prior to 20-F Filing } \\
\hline No Form 20-F filed for year & & (3) & (3) \\
\hline Final Sample 6-K Documents & $\underline{122}$ & $\underline{72}$ & $\underline{194}$ \\
\hline \multicolumn{4}{|l|}{ Sample 20-F Documents } \\
\hline \multicolumn{4}{|l|}{ Form 20-F documents for 80 firms for two-year period } \\
\hline Companies filing only one 20-F for two-year period & & (12) & \\
\hline No CRSP data for specific event period & & (7) & \\
\hline No 6-Ks filed in fiscal year of 20-F filing & & (5) & \\
\hline No 20-F filing date recorded at SEC & & $(4)$ & \\
\hline & & 132 & \\
\hline
\end{tabular}

Because Form 6-Ks can be filed any time throughout the year, many times significant information is reported about the sample companies in the media within the event period of the SEC document release. A search of both the Wall Street Journal Index and major newspapers reported through Lexis/Nexis revealed that 79 of the sample Form 6-Ks filing dates were within the three-day period of an earnings announcement and 76 were filed within the period of the release of other significant information, including dividend declarations, merger/acquisition announcements, new product information and other significant business transactions. It is unknown whether the market is reacting to the information provided in the SEC document or the media information reported. Previous research and the fact that newspaper information is extensively available would presume the market reaction would be for the media information. Because this study could not differentiate the effect of the market reaction between the Form 6-K document and the media release, these sample documents could not be included in the final tests. The information provided in the SEC document is almost always more extensive than the information provided in the media release, however. In addition, only five of the 155 media releases causing the respective 6-Ks to be removed discussed financial figures based on the differences between foreign and U.S. GAAP.

Additional reductions to the sample 6-K documents included 59 documents which duplicated the same financial information, 22 6-Ks filed after the Form 20-F filing, six documents for which no CRSP data was available for the specific event periods, and one document considered an outlier due to its value being $25,000 \%$ higher than the test value. In addition, the non-U.S. GAAP sample was adjusted for 53 6-Ks filed by firms that had previously reported U.S. GAAP information in the same fiscal year and three 6-Ks for which no Form 20-F was filed during the year. The exclusions significantly decreased the sample sizes to 45 and 28 firms respectively for U.S. GAAP information and non- 
U.S. GAAP data. The number of documents in each of the samples decreased dramatically as well from 276 to 122 for the U.S. GAAP data and from 217 to 72 for the non-U.S. GAAP data.

Assuming each of the 80 companies files a $20-\mathrm{F}$ in each of the two-year period, the available 20-F documents would be 160 . However, several adjustments had to be made to this filing assumption. The first adjustment includes twelve 20-Fs for which companies only filed one 20-F in the two-year period. Additional adjustments to the Form 20-F sample documents include seven documents for which no CRSP data was available for the specific report period, five documents for which no Form 6-Ks were filed with the SEC in that specific fiscal year, and four 20-Fs for which no reporting date was available from the SEC. The final 20-F sample documents totaled 132. Of these 13220 -Fs, 50 (38\%) had no U.S. GAAP disclosed in Form 6-K before the 20-F filing and $82(62 \%)$ had previous U.S. GAAP information disclosed.

\section{Empirical Results And Analyses}

Partition A of Table 3 presents the descriptive statistics for $\mathrm{AR}_{\mathrm{iA}}, \mathrm{AR}_{\mathrm{iNA}}$, and $\mathrm{DIFF}_{\mathrm{i}}$ for all firms providing U.S. GAAP data and those firms providing non-U.S. GAAP data only. Partition B of Table 3 presents the results of the tests of significance for the above sets of information. The t-statistic is employed to determine if the information provided by the foreign firms is significant, therefore "relevant". The t-statistic was not statistically significant for either of the partitions. Employing an alpha level of .05 for significance, $\mathrm{Ho}_{1}$, and $\mathrm{Ho}_{2}$ cannot be rejected. The above results can be interpreted to mean there is not enough evidence to conclude that any financial information provided in Form 6-K is relevant to investors.

\section{Table 3: Form 6-K Relevance Tests}

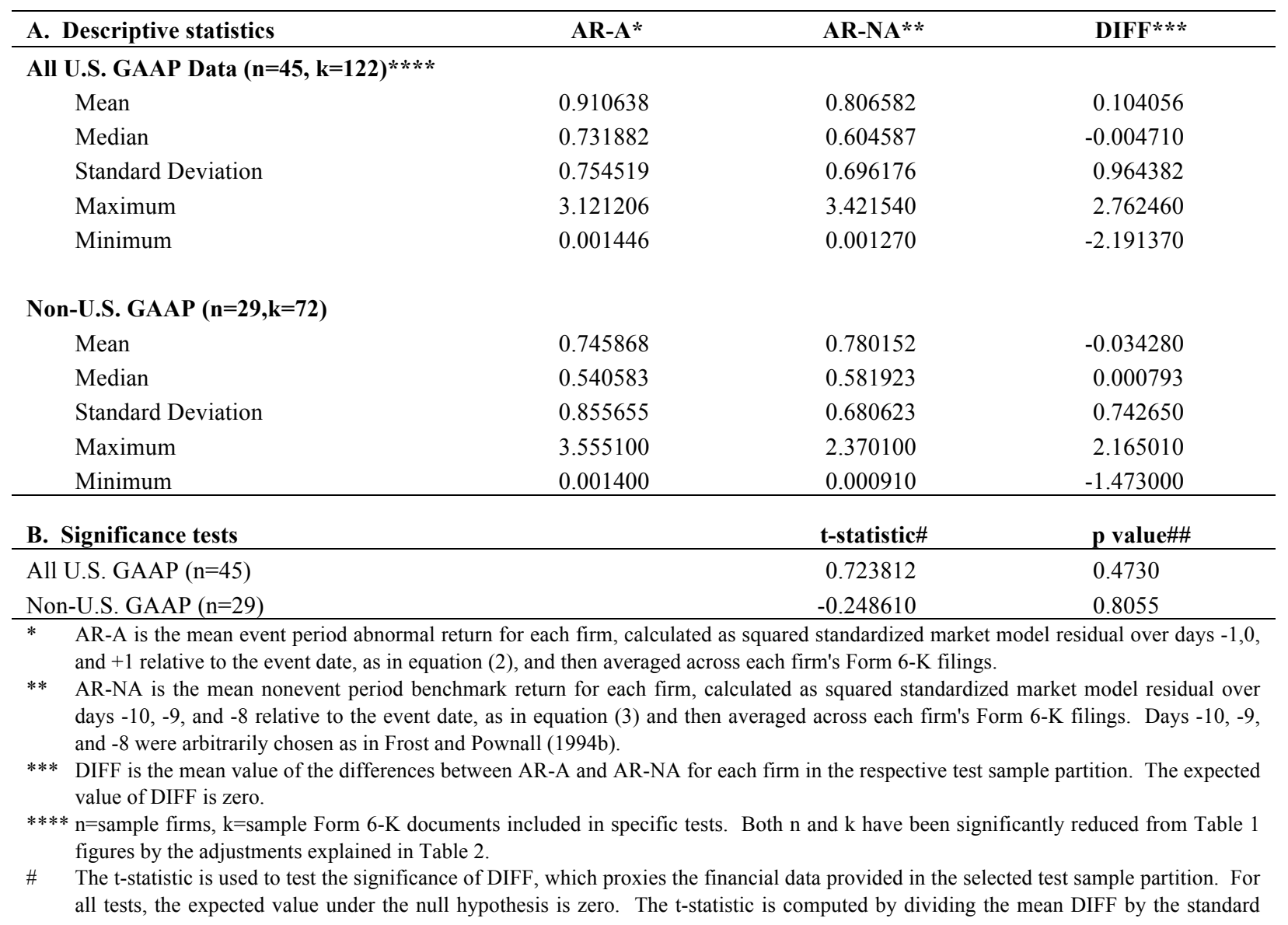


deviation of the firms' DIFFs divided by the square root of $n$.

\#\# The $\mathrm{p}$ value is determined by comparing the $\mathrm{t}$-statistic to the $\mathrm{t}$ table using a two-tailed test of significance and the appropriate degrees of freedom (df).

In addition, tests were conducted to determine if the results would differ based on partitioning the sample into firms listing on the NYSE or the ASE and firms listing on NASDAQ. The results were not statistically significant for any sample partition.

Tests were also conducted to determine if the results would differ based on partitioning the sample into the respective reporting period - interim or annual - of the 6-Ks. The results were not statistically significant for either sample partition and there was not a statistical difference between the significance of either report's information.

Table 4 presents the results for the Form 20-F relevancy and comparison tests. Partition A of Table 4 presents the descriptive statistics for $\mathrm{AR}_{\mathrm{iA}}, \mathrm{AR}_{\mathrm{iNA}}$, and $\mathrm{DIFF}_{\mathrm{i}}$ for those firms disclosing no prior U.S. GAAP data and for those firms disclosing prior U.S. GAAP data. Partition B of Table 4 presents the results of the tests of significance for the above sets of information. The t-statistic revealed no statistically significant results.

Table 4: Form 20-F Relevance Tests And Comparisons

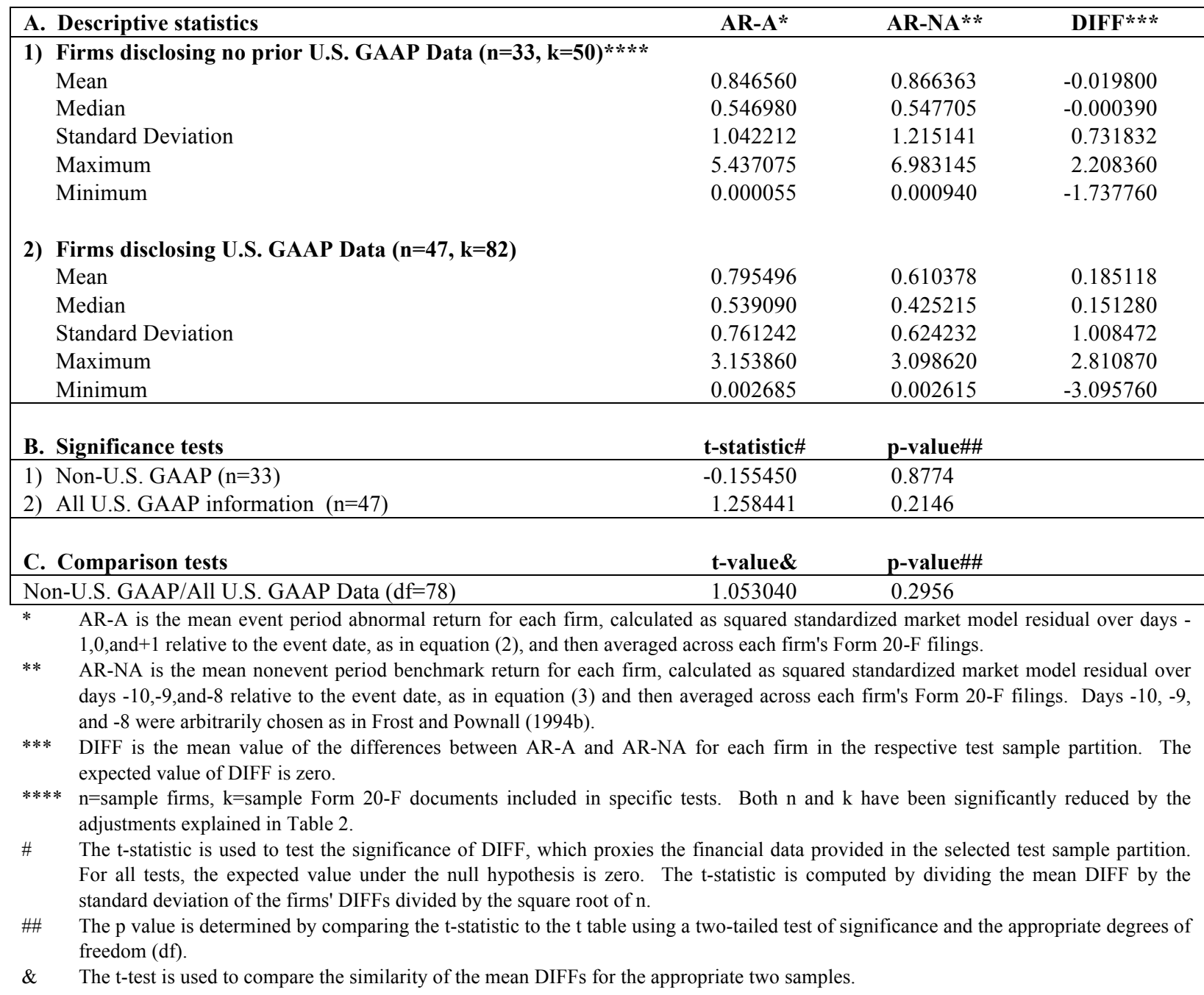


Employing an alpha level of 5\% for significance, the above results can be interpreted to mean that there is not enough evidence to conclude that the financial information provided in the Form 20-F filing is relevant for those companies providing either U.S. GAAP-information or non-U.S. GAAP data prior to the Form 20-F filing.

Partition $\mathrm{C}$ of Table 4 presents the results to the comparison tests. The sample firms which provided no prior U.S. GAAP data are compared to the sample firms disclosing any type of U.S. GAAP data. Employing an alpha level of $5 \%$ for significance, no statistically significant results are found and $\mathrm{Ho}_{3}$ cannot be rejected. The above results are interpreted to mean that the relevance of the information provided in the Form 20-F filing for those companies providing U.S. GAAP data before the 20 -F filing is not significantly different from the relevance of the information provided in the Form 20-F filing for those companies not providing prior U.S. GAAP data.

\section{Conclusions}

The main goal of this research study was to determine whether any U.S. GAAP financial information is provided by foreign firms to the SEC in Form 6-K prior to the annual Form 20-F filing. Of the 80 sample firms, 47 reported some type of U.S. GAAP information on Form 6-K prior to the annual Form 20-F filing. Relevancy tests were then performed as the second goal of the study to determine whether the U.S. GAAP information filed on SEC Form 6-K provided significant information to investors. These tests were insignificant, not allowing this study to conclude that the U.S. GAAP information filed on Form 6-K is relevant to investors. Furthermore, the results of these tests did not vary based on the exchange listing or whether the reporting period was for an interim or annual period.

The third goal of this study was to determine whether there was a difference between the relevance of the information provided in Form 20-F for those companies not disclosing any U.S. GAAP information in Form 6-K prior to the Form 20-F filing date and those companies providing prior U.S. GAAP data. Comparison of the 33 non-disclosing companies to the 47 U.S. GAAP disclosing companies did not reveal a significant difference, an unexpected finding.

Given the results of these tests, this study cannot conclude that U.S. GAAP information filed by foreign firms on a timely basis with the SEC is relevant. One of the possible reasons this study could not find significance in the respective SEC documents is the fact that foreign firms were not required to file on the SEC's EDGAR Database. Even though foreign firms were not required to file required documents electronically on EDGAR, one would expect large multinational companies to voluntarily provide this information in a manner consistent with their U.S. counterparts. This was not the case, however, as very few of the sample firms provided Form 20-Fs or Form 6-Ks through EDGAR. ${ }^{7}$ The SEC just recently on November 14, 2002, made it mandatory for foreign firms to file Forms 20-F and 6-K through EDGAR. Essentially all of the sample companies still listing with the SEC filed their recent financial documents through EDGAR. This is great news for investors as the EDGAR system provides easy access to the timely financial information provided in Forms 6-K and Form 20-F.

Another possible explanation for the insignificant reactions to the information presented in the SEC documents in this study is the dominance of U.K. firms in all of the sample tests. Firms from the U.K. tend to have significant analyst following which would support Fulkerson and Meek's [1998] conclusions that U.S. GAAP reconciliations may be more relevant to firms with little or no analyst following.

In addition, there is the possibility that some, if not all, of the information contained in 6-K filings has already been released to the markets prior to the 6-K filing dates through informal communication with analysts or other sources. Analysts may even be able to anticipate U.S. GAAP results based on prior year's information and non-U.S. GAAP information that is often released prior to U.S. GAAP information.

This study discovered that Form 6-K documents which can be filed any time throughout the year contain more timely financial information for most foreign companies than the annual Form 20-F document due six months after a 
firm's fiscal year end. The public availability of SEC documents through EDGAR make them an excellent source of information when evaluating foreign firms.

\section{Suggestions For Further Research}

Further research should focus on the use of the Form 6-K and 20-F documents that are now available on the EDGAR Database. The types of financial information provided can be examined as well as what companies adhere to the SEC EDGAR filing requirement. SEC documents of companies from additional countries can be examined along with documents of companies from various industries.

\section{References}

1. Bandyopadhyay, S., J. Hanna, and G. Richardson, "Capital Market Effects of U.S.-Canada GAAP Differences," Journal of Accounting Research, Vol. 32, No. 2, 262-277, 1994.

2. Barth, M. and G. Clinch, "International Accounting Differences and Their Relation to Share Prices: Evidence from U.K., Australian, and Canadian Firms," Contemporary Accounting Research, 13 (1): 135-70, 1996.

3. Bayless, R., J. Cochrane, T. Harris, J. Leisenring, J. McLaughlin, and J. Wirtz, "International Access to U.S. Capital Markets - An AAA Forum on Accounting Policy," Accounting Horizons, Volume 10, Number 1, March, 75-94, 1996.

4. Chan, K. and G. Seow, "The Association Between Stock Returns and Foreign GAAP Earnings Versus Earnings Adjusted to U.S. GAAP,” Journal of Accounting \& Economics, Volume 21, 139-58, 1996.

5. Easton, P. and M. Zmijewski, "SEC Form 10K/10Q Reports and Annual Reports to Shareholders: Reporting Lags and Squared Market Model Prediction Errors," Journal of Accounting Research, Spring, 113-129, 1993.

6. Foster, T., D. Jenkins, and D. Vickrey, "Additional Evidence on the Incremental Information Content of the 10K," Journal of Business, Finance, and Accounting, Volume 10, Issue 1, 57-66, 1993.

7. Foster, T. and D. Vickrey, "Information Content of the 10-K," Accounting Review, 1978.

8. Frost, C. and G. Pownall, "Accounting Disclosure Practices in the United States and the United Kingdom," Journal of Accounting Research, Vol. 32, No. 1, 75-102, 1994a.

9. Frost, C. and G. Pownall, "A Comparison of the Stock Price Response to Earnings Disclosures in the United States and the United Kingdom," Contemporary Accounting Research, 59-83, 1994b.

10. Fulkerson, C. and G. Meek, "Analysts' Earnings Forecasts and the Value Relevance of 20-F Reconciliations from non-U.S. to U.S. GAAP,” Journal of International Financial Management \& Accounting, February, 1-15, 1998.

11. Hanks, S., "Big Board's Problem with Foreign Listings,” Wall Street Journal, 16 January, A13, 1992.

12. Harrington, J., "An Examination of the Information Content of Foreign GAAP Reconciliations," The International Journal of Business Disciplines, Summer, 17-32, 1998.

13. Jarrell, G., "SEC Crimps Big Board's Future," Wall Street Journal, 19 June, 1992.

14. McQueen, P., "The Information Content of Foreign and U.S. GAAP Earnings in SEC Form 20-F," CUNYBaruch College Working Paper, April, 1993.

15. Meek, G., "U.S. Securities Market Responses to Alternate Earnings Disclosures of Non-U.S. Multinational Corporations," Accounting Review, April, 394-402, 1983.

16. Pope, P. and W. Rees, "International Differences in GAAP and the Pricing of Earnings," Journal of International Financial Management and Accounting, 4:3, pp. 190-219, 1992.

17. Rees, L., "The Information Contained in Reconciliations to Earnings Based on U.S. Accounting Principles by Non-U.S. Companies," Accounting and Business Research, Volume 25, Number 100, 301-10, 1995.

18. Rees, L. and P. Elgers, "The Market's Valuation of Nonreported Accounting Measures: Retrospective Reconciliations of Non-U.S. and U.S. GAAP," Journal of Accounting Research, Volume 35, Number 1, Spring, 115-27, 1997.

19. Salwen, K., "Big Board Finds Ally in Bid to List Foreign Concerns," Wall Street Journal, 9 May, C12, 1991.

20. Saudagaran, S. and G. Meek, "A Review of Research on Financial Reporting in International Capital Markets," Journal of Accounting Literature, Volume 16, 127-59, 1997. 
21. Siconolfi, M. and K. Salwen, "Big Board, SEC Fight Over Foreign Stocks," Wall Street Journal, 13 May, 1992.

22. Stice, E., "The Market Reaction to 10-K and 10-Q Filings and to Subsequent "The Wall Street Journal" Earnings Announcements," Accounting Review, Volume 56, Number 1, January, 42-55, 1991.

23. Zarzeski., M., "Spontaneous Harmonization Effects of Culture and Market Forces on Accounting Disclosure Practices," Accounting Horizons, Volume 10, Number 1, March, 18-37, 1996.

\section{Endnotes}

1. See Salwen [1991], Hanks [1992], Jarrell [1992], Siconolfi \& Salwen [1992], and Bayless et. al. [1996].

2. Amir, Harris, and Venuti [1993] examined both annual reports and Form 20-Fs to find annual U.S. GAAPreconciled data. They used the earlier of the annual report or Form 20-F filing date for their event date. They found that U.S. GAAP-reconciled data was first disclosed in the Form 20-F filing for $421(90 \%)$ of their 467 sample observations. In addition, Harrington [1998] performed an extended search of the first disclosure of annual GAAP-reconciled data to include the earliest of a media release, the annual report filing, or the SEC Document filing. Results indicated that of 416 sample firm years, sixteen (4\%) first reported annual GAAP-reconciled information with their annual earnings announcement, $106(25 \%)$ in the annual report, and 294 (71\%) at the Form 20-F or 10-K filing date.

3. Previous research has also stated that U.S. GAAP information is available before the annual report filing date via the financial analysts reports. For example, analysts employ "information retrievers" who work onsite at the Washington, D.C. SEC Reading Room to gather this data as soon as it is filed. The information retrievers then communicate it to the analysts within minutes.

4. Exempt firms are those companies registered on NASDAQ prior to October 6, 1983. These firms are not required to provide any U.S. GAAP information to the SEC.

5. The sample period covered fiscal years 1993 and 1994. Fiscal years in 1993 began as early as July 1, 1992 and fiscal years in 1994 ended as late as June 30,1995. Therefore, combining the two fiscal years resulted in 759 market days available in the sample period. In addition, an alternative estimation period was tested using 253 days prior to the first event period of the sample. The results are similar.

6. In addition, normal nonevent periods are examined containing days, -18 to $-20,-16$ to $-18,-13$ to -15 , and -10 to -12 . These results were much better than the -8 to -10 period, causing the tests to show some significance in the information provided. However, the significant results were not consistent between the normal nonevent periods. Therefore, this study chose to report the results using the normal period of -8 to -10 , consistent with Frost and Pownall's [1994b] arbitrary nonevent period.

7. As of January 22, 1999, 94 Form 20-Fs from 62 different companies were filed on the EDGAR Database. Only three of this sample's firms were included in that tally. For the same time period, 150 Form 6-Ks from 27 different companies were filed on EDGAR, including only two firms from this sample. 
Notes 


\section{Do Not Print This Page!!}

${ }^{1}$ See Salwen [1991], Hanks [1992], Jarrell [1992], Siconolfi \& Salwen [1992], and Bayless et. al. [1996].

${ }^{2}$ Amir, Harris, and Venuti [1993] examined both annual reports and Form 20-Fs to find annual U.S. GAAP-reconciled data. They used the earlier of the annual report or Form 20-F filing date for their event date. They found that U.S. GAAP-reconciled data was first disclosed in the Form 20-F filing for $421(90 \%)$ of their 467 sample observations. In addition, Harrington [1998] performed an extended search of the first disclosure of annual GAAP-reconciled data to include the earliest of a media release, the annual report filing, or the SEC Document filing. Results indicated that of 416 sample firm years, sixteen (4\%) first reported annual GAAP-reconciled information with their annual earnings announcement, 106 $(25 \%)$ in the annual report, and $294(71 \%)$ at the Form $20-\mathrm{F}$ or $10-\mathrm{K}$ filing date.

${ }^{3}$ Previous research has also stated that U.S. GAAP information is available before the annual report filing date via the financial analysts reports. For example, analysts employ "information retrievers" who work onsite at the Washington, D.C. SEC Reading Room to gather this data as soon as it is filed. The information retrievers then communicate it to the analysts within minutes.

${ }^{4}$ Exempt firms are those companies registered on NASDAQ prior to October 6, 1983. These firms are not required to provide any U.S. GAAP information to the SEC.

${ }^{5}$ The sample period covered fiscal years 1993 and 1994. Fiscal years in 1993 began as early as July 1, 1992 and fiscal years in 1994 ended as late as June 30, 1995. Therefore, combining the two fiscal years resulted in 759 market days available in the sample period. In addition, an alternative estimation period was tested using 253 days prior to the first event period of the sample. The results are similar.

${ }^{6}$ In addition, normal nonevent periods are examined containing days, -18 to $-20,-16$ to $-18,-13$ to -15 , and -10 to -12 . These results were much better than the -8 to -10 period, causing the tests to show some significance in the information provided. However, the significant results were not consistent between the normal nonevent periods. Therefore, this study chose to report the results using the normal period of -8 to -10 , consistent with Frost and Pownall's [1994b] arbitrary nonevent period.

${ }^{7}$ As of January 22, 1999, 94 Form 20-Fs from 62 different companies were filed on the EDGAR Database. Only three of this sample's firms were included in that tally. For the same time period, 150 Form 6-Ks from 27 different companies were filed on EDGAR, including only two firms from this sample. 